\title{
Litter Dynamics in a Forest Dune at Restinga da Marambaia, RJ, Brazil
}

\author{
Rodrigo Camara ${ }^{1}$, Marcos Gervasio Pereira ${ }^{1}$, Luis Fernando Tavares Menezes ${ }^{2}$, \\ Aurora Bayma Segall ${ }^{1}$, João Sérgio Ramalho Castro ${ }^{1}$ \\ ${ }^{1}$ Departamento de Solos, Universidade Federal Rural do Rio de Janeiro - UFRRJ, Seropédica/RJ, Brasil \\ ${ }^{2}$ Centro Universitário Norte do Espírito Santo - CEUNES, Universidade Federal do Espírito Santo - UFES, São Mateus/ES, Brasil
}

\begin{abstract}
Restingas are extremely degraded, tropical sandy ecosystems and are poorly studied in terms of nutrient cycling. The present study aimed to evaluate litter dynamics in a forest dune at Restinga da Marambaia, RJ. Litterfall was collected monthly using two parallel transects installed $200 \mathrm{~m}$ apart from each other with 15 litter traps $\left(0.25 \mathrm{~m}^{2}\right)$, over two consecutive years. The litterfall was sorted into leaves, twigs, flowers, fruits, and refuse. Litter decomposition was evaluated by the ratio between litterfall and litter layer on the soil surface, which was estimated every four months by quadrats $\left(0.25 \mathrm{~m}^{2}\right)$ placed next to the litter traps. The average annual litterfall was low $\left(6.8 \mathrm{t} \mathrm{ha}^{-1}\right.$ year $\left.{ }^{-1}\right)$, mostly constituted by leaves $(70 \%)$, with the greatest deposits occurring during the rainy season. The decomposition rate was low $(0.85)$ and the turnover time was long (439 days). This litter dynamic contributes to the nutrient economy.
\end{abstract}

Keywords: litter, nutrient cycling, sandy coastal plain, tropical forest. 


\section{INTRODUCTION}

Restingas are marginal habitats that occur in sandy coastal plains and belong to the Atlantic Rainforest complex. Restingas used to cover about $79 \%$ of the Brazilian coast (Menezes et al., 2010) and most of Rio de Janeiro State coast, but the majority of these ecosystems are in some way altered, totally or partially degraded, due to occupation over the last five centuries (Rocha et al., 2007). These authors identified 21 restinga remnants in the Rio de Janeiro State, totaling 105.29 ha, and highlighted that the most common causes of degradation are removal of vegetation to establish property developments, planting of exotic species and changes to the original substrate.

In restingas, plants are exposed to marine and fluvial-marine influence, heat, flooding, drought, wind, salinity and low natural soil fertility. Thus, plants community formation is based on positive ecological interactions between a few species (Scarano et al., 2001). For example, bromeliads are called keystone species because they contribute to the increasing diversity in restingas (Cogliatti-Carvalho et al., 2001). In Restinga da Marambaia, which is located in the municipality of Rio de Janeiro, the terrestrial bromeliads dominate the dense herbaceous layer on the floor of a forest dune. The aboveground biomass of such bromeliads involves a high concentration of nutrients (Souza et al., 2016) which improves soil fertility in the area by leaf litter (Pereira et al., 2005).

Litterfall is the primary process by which nutrients are transferred from aboveground vegetation, through the breakdown of organic material which releases mineral nutrients into the soils in forms available to plants and microorganisms (Vitousek \& Sanford, 1986). There is incipient information about different aspects of nutrient cycling in restingas, where both litterfall and litter decomposition are low (Moraes et al., 1999; Pires et al., 2006; Bonadiman, 2007; Castanho \& Oliveira, 2008; Paula et al., 2009; Pereira et al., 2012).

The low rates of litter decomposition in restingas are due to the high concentrations of cellulose and lignin (Pereira et al., 2012) and high lignin:N ratio and C:N ratio (Castanho \& Oliveira, 2008). This feature, which is observed in coriaceous textured leaves, is a strategy to reduce evapotranspiration losses. Such processes allow the slow return of nutrients into the soil, which minimizes losses from the soil-plant system by leaching and maximizes the use of nutrient absorption by plants (Pires et al., 2006; Bonadiman, 2007; Paula et al., 2009). The high nutrient translocation before the leaves senescence in restingas is another evident strategy of the nutrient economy or high efficiency of nutrient use (Moraes \& Domingos, 1997). Studies that focus on the dynamics of nutrient cycling in restingas permit an understanding of ecosystem functioning, which can support decisions not only for their conservation and preservation, but also with a view to their rehabilitation.

The present study aimed to evaluate the litterfall and decomposition along two consecutive years, in a forest dune at restinga da Marambaia, Rio de Janeiro, Brazil. We considered the hypothesis that (1) there are differences between the years in terms of litterfall and decomposition; (2) litter dynamics in the forest dune is slow in comparison to other forest ecosystems in the Atlantic Rainforest biome.

\section{MATERIAL AND METHODS}

Restinga da Marambaia presents approximately $49.40 \mathrm{~km}^{2}$, distributed in the municipalities of Rio de Janeiro, Itaguaí and Mangaratiba in Rio de Janeiro State (Roncarati \& Menezes, 2005). The area is in a relatively good state of preservation, because it is located within a military area and has restricted access. The macroclimate of the region is classified as Aw (Tropical Rainy) with a rainy summer and dry winter according to Köppen (Alvares et al., 2013). Monthly total precipitation and average temperature data was provided by INMET $6^{\text {th }}$ District of Rio de Janeiro (Figure 1). According to this data, the total rainfall was $1,062.2 \mathrm{~mm}$ and $1,233.1 \mathrm{~mm}$ from September 1999 to August 2000 (Year1) and from September 2000 to August 2001 (Year2), respectively, while the average annual temperature was $24.2^{\circ} \mathrm{C}$ and $25.3^{\circ} \mathrm{C}$, respectively.

This study was conducted in a forest dune situated on a slope at the east end of Marambaia $\left(23^{\circ} 03^{\prime} \mathrm{S} ; 43^{\circ} 36^{\prime} \mathrm{W}\right)$, lying approximately $800 \mathrm{~m}$ from the ocean and $300 \mathrm{~m}$ from Sepetiba Bay. This forest grows on the top of a single dune with about $30 \mathrm{~m}$ height, covering about 527 ha and corresponding to approximately $10.7 \%$ of the total area of Restinga da Marambaia. The vegetation profile in the dune varies from shrub, located in the lower third, 


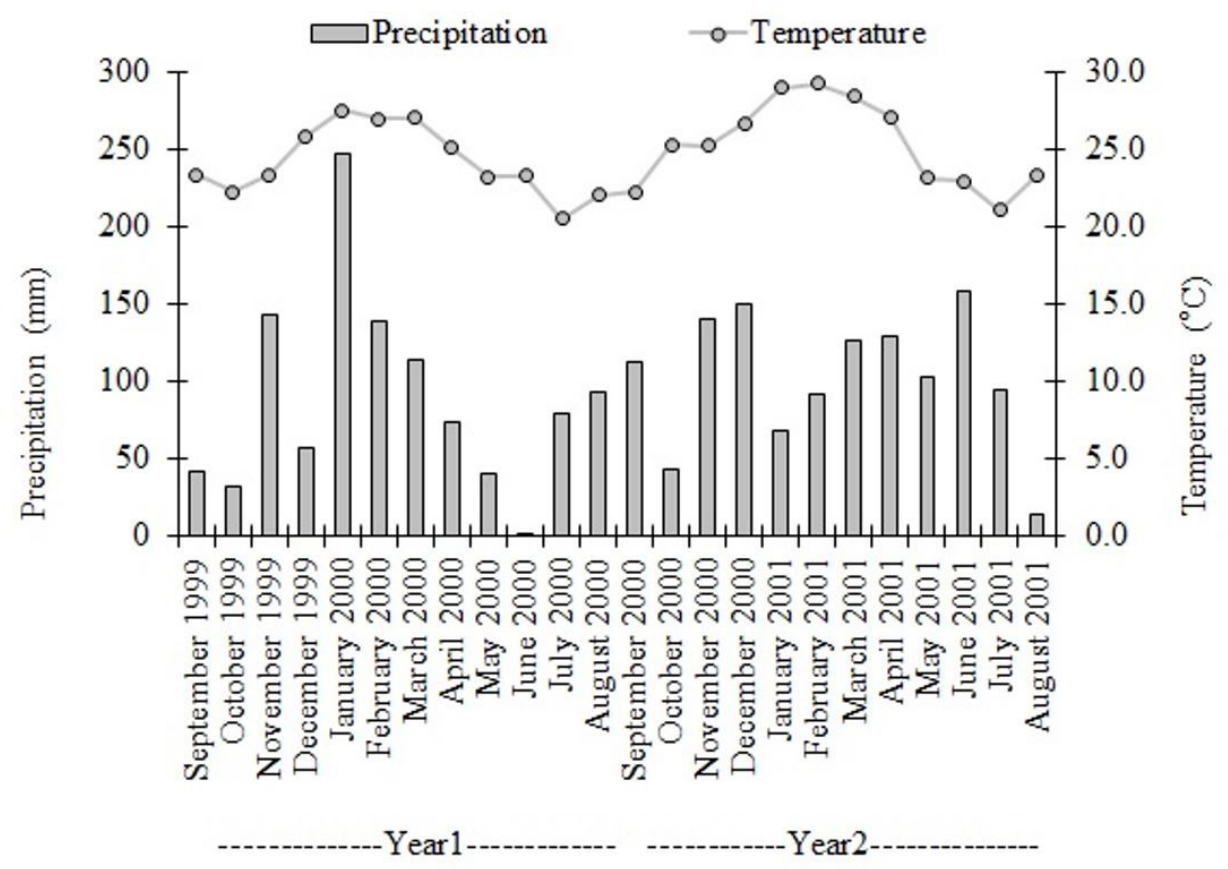

Figure 1. Monthly precipitation and temperature distributed over Year1 and Year2 at Restinga da Marambaia, Rio de Janeiro, Brazil.

to an arboreal community which predominates in the upper third (Fraga et al., 2010).

The forest dune presents an average height of $8 \mathrm{~m}$ on the slope facing the ocean, and an average height of $15 \mathrm{~m}$ on the slope facing Sepetiba Bay. The herbaceous layer is dense and dominated by bromeliads. The tree layer presents 53 tree species belonging to 25 families, with Myrtaceae being the family with the largest number of species (Eugenia arenaria, E. copacabanensis, E. ovalifolia, E. sulcata). The tree species of greatest importance are Ocotea notata (34.06), Maytenus obtusifolia (25.80), Byrsonima sericea (19.69), Cupania emarginata (17.18), Aspidosperma parvifolium (16.20), Eugenia ovalifolia (15.23), Erythroxylum ovalifolium (14.91), Marlierea schottii (11.27) and Pseudopiptadenia contorta (10.13).

The soil belongs to the Quartzipsamment order (Menezes et al., 2005). Soil fertility increases in the upper third of the dune, in comparison to the lower third, which presents the highest aluminum content and lowest nutrient content (Fraga et al., 2010). Regarding the topsoil chemical attributes $(0-0.10 \mathrm{~cm})$ in the upper third of the dune, Fraga et al. (2010) obtained the following results: $\mathrm{K}^{+}: 29.67 \mathrm{mg} \mathrm{kg}^{-1} ; \mathrm{Ca}^{2+}: 3.27 \mathrm{cmol}_{\mathrm{c}} \mathrm{kg}^{-1}$; $\mathrm{Mg}^{2+}: 1.62 \mathrm{cmol}_{\mathrm{c}} \mathrm{kg}^{-1} ; \mathrm{Na}^{+}: 0.14 \mathrm{cmol}_{\mathrm{c}} \mathrm{kg}^{-1}$.
In August/1999, we installed a total of 30 litter traps, 15 traps each along two parallel lines (transects) perpendicular to the sea line and separated from each other by $200 \mathrm{~m}$, in the forest dune. We located transects in the upper third of the dune, facing the ocean. The litter traps were distributed at intervals of $10 \mathrm{~m}$ along each transect. The traps were made of wooden $0.5 \mathrm{~m} \times 0.5 \mathrm{~m}$ quadrats $\left(0.25 \mathrm{~m}^{2}\right)$ with $1 \mathrm{~mm}^{2}$ nylon mesh and held $10 \mathrm{~cm}$ off the ground (Arato et al., 2003). The contents of the litter traps were collected monthly in Year 1 and Year2 and placed in paper bags. These bags were dried in a fan forced oven $\left(65^{\circ} \mathrm{C}, 48 \mathrm{~h}\right)$ in the laboratory after each collection (Correia et al., 2016).

Afterwards, the litterfall was sorted into five fractions: leaves, small twigs ( $\leq 2 \mathrm{~cm}$ in diameter), flowers, fruits, and refuse (small $<2 \mathrm{~mm}$, miscellaneous plant and animal debris and frass) (Pereira et al., 2012), and then weighed. The dry mass obtained monthly ( $\mathrm{g} \mathrm{m}^{-2}$ month $^{-1}$ ) was transformed into $t \mathrm{ha}^{-1}$ month $^{-1}$. The litterfall was evaluated according to the equation: $\mathrm{LF}=(\Sigma \mathrm{AL} x 10,000) / \mathrm{TA}$; where: $\mathrm{AL}=$ annual average of litterfall $\left(\mathrm{t} \mathrm{ha}^{-1}\right.$ year $\left.^{-1}\right) ; \mathrm{ML}=$ monthly litterfall $\left(\mathrm{t} \mathrm{ha}^{-1}\right.$ month $\left.^{-1}\right) ; \mathrm{TA}=$ trap area $\left(\mathrm{m}^{2}\right)$ (Lopes et al., 2002). 
The total small litter lying on the forest floor was removed within a $0.5 \mathrm{~m} \times 0.5 \mathrm{~m}$ quadrat $\left(0.25 \mathrm{~m}^{2}\right)$ (Patricia \& Morellato, 1992) made of PVC tubes. Sampling ( $\mathrm{n}=15$ samples / transect) was performed next to the litter traps, every four months in Yearl and Year2, at the end of September, December, March and June. This material was dried and weighed similarly as for litterfall.

The rate of litter decomposition indirectly represents the rate at which litter nutrients return to the soil and become available again for plants (Vital et al., 2004). This rate $(\mathrm{K})$ was obtained by the equation of dynamic equilibrium (Olson, 1963): $\mathrm{K}=\mathrm{L} / \mathrm{X}$, where $\mathrm{L}=$ annual small litterfall; $\mathrm{X}=$ small litter lying on the forest floor. This methodology was also used in other studies (Arato et al., 2003; Vital et al., 2004; Pires et al., 2006). The average time needed to complete renewal of litter accumulated on the forest floor (tr) was determined by: $\operatorname{tr}=1 / \mathrm{K}$ (Hopkins, 1966).

Factorial ANOVA was performed to evaluate statistical differences between the years in terms of total litterfall and fractions $\left(\mathrm{t} \mathrm{ha}^{-1} \mathrm{ano}^{-1}\right)$. In this analysis, we considered the dry mass as the dependent variable, and the year and month as the independent or predictor variables. Levene's test was employed to evaluate the homogeneity of variances, which was rejected. Afterwards, we performed the Mann-Whitney U non-parametric test with the aim of identifying the differences between the years, and months $\left(\mathrm{t} \mathrm{ha}^{-2}\right)$ in terms of total litterfall and fractions, in each year. For this purpose, we calculated the mean dry mass between transects. We also employed the statistical analysis of a generalized linear model in order to evaluate the association between climatic variables (precipitation, temperature, the independent or predictor variables), and the fractional and total litterfall deposits (dependent variables). In all the statistical analyses, which were performed with STATISTICA software version 8.0., we considered $\mathrm{p}<0.05$ as the level for significance.

\section{RESULTS AND DISCUSSION}

In the forest dune, we observed significant interaction between year and month for leaf ( $p=0.000000)$, twig $(p=0.006861)$, refuse $(p=0.000000)$, and total litterfall ( $p=0.000000)$ deposits. There was an isolated significant effect for both the year $(\mathrm{p}=0.002100)$ and month $(p=0.000000)$ for flower deposits. In contrast, there was no significant impact from either the year or month in relation to fruit deposits.

Leaf, flower, and total litterfall deposits were significantly higher during Year1, whereas refuse deposits were significantly lower in Year1, when comparing the years (Table 1). There were no significant differences between the years in terms of twig and fruit deposits.

The average total litterfall was approximately 6.6 t ha $^{-1}$ year $^{-1}$ (Table 1). This value is close to the average litterfall in South American tropical forests that grow in white sand and poor soils which is $5.4 \mathrm{t} \mathrm{ha}^{-1} \mathrm{yr}^{-1}$, which is lower than in ferralsols where the average litterfall is $7.1 \mathrm{t} \mathrm{ha}^{-1} \mathrm{yr}^{-1}$ (Chave et al., 2010). The total litterfall in non-flooding restinga forests is lower than in the Atlantic Rain Forests (Table 2).

This pattern is a consequence of the lower fertility of the soil in restingas (low clay and organic matter content, low cation exchangeable capacity values and high aluminum saturation values), in comparison with

Table 1. Annual deposits ( $\left.\mathrm{tha}^{-1} \mathrm{yr}^{-1}\right)$ of total litterfall and fractions and the relative contribution (\%) in Year1 and Year2, in a forest dune at Restinga da Marambaia, Rio de Janeiro State, Brazil.

\begin{tabular}{|c|c|c|c|c|c|c|}
\hline \multirow[t]{2}{*}{ Litter } & Deposits & $\begin{array}{c}\text { Relative } \\
\text { contribution }\end{array}$ & Deposits & $\begin{array}{c}\text { Relative } \\
\text { contribution }\end{array}$ & Deposits & $\begin{array}{c}\text { Relative } \\
\text { contribution }\end{array}$ \\
\hline & \multicolumn{2}{|c|}{ Year1 } & \multicolumn{2}{|c|}{ Year2 } & \multicolumn{2}{|c|}{ Average } \\
\hline Leaves & $5.3 \mathrm{~A}(0.8)$ & 75 & $4.6 \mathrm{~B}(0.9)$ & 74 & $4.9(0.8)$ & 75 \\
\hline Twigs & $1.1 \mathrm{~A}(0.5)$ & 15 & $1.0 \mathrm{~A}(0.4)$ & 16 & $1.0(0.4)$ & 16 \\
\hline Flowers & $0.2 \mathrm{~A}(0.2)$ & 3 & $0.1 \mathrm{~B}(0.1)$ & 2 & $0.2(0.1)$ & 2 \\
\hline Fruits & $0.2 \mathrm{~A}(0.2)$ & 3 & $0.2 \mathrm{~A}(0.1)$ & 3 & $0.2(0.2)$ & 3 \\
\hline Refuse & $0.2 \mathrm{~B}(0.1)$ & 4 & $0.3 \mathrm{~A}(0.1)$ & 5 & $0.3(0.1)$ & 4 \\
\hline Total & $7.0 \mathrm{~A}(1.0)$ & 100 & $6.2 \mathrm{~B}(1.0)$ & 100 & $6.6 \mathrm{~B}(0.9)$ & 100 \\
\hline
\end{tabular}

Mean values, with standard deviation in parenthesis, followed by the same letter in a line indicate no statistical difference between the years (Mann-Whitney U test, $\mathrm{p}<0.05)$. 
Table 2. Total annual litterfall $\left(\mathrm{t} \mathrm{ha}^{-1}\right.$ year $\left.^{-1}\right)$ and relative contribution of leaves $(\%)$ in some Brazilian tropical forests.

\begin{tabular}{|c|c|c|c|}
\hline Ecosystem/Local & $\begin{array}{c}\text { Total annual } \\
\text { litterfall }\end{array}$ & $\begin{array}{c}\text { Contribution of } \\
\text { leaves }\end{array}$ & Study \\
\hline \multicolumn{4}{|l|}{ Non-flooding Restinga forest } \\
\hline Ilha do Cardoso, SP & 3.9 & 75 & Moraes et al. (1999) \\
\hline Ilha do Mel, PR & 5.1 & 75 & Pires et al. (2006) \\
\hline Restinga da Marambaia, RJ & 6.6 & 75 & This study \\
\hline Average & 5.2 & 75 & \\
\hline \multicolumn{4}{|l|}{ Seasonally flooded Restinga forest } \\
\hline FF1, Restinga da Marambaia, RJ & 11.3 & 71 & Paula et al. (2009) \\
\hline FF2, Restinga da Marambaia, RJ & 10.8 & 67 & \\
\hline FF3, Restinga da Marambaia, RJ & 11.1 & 64 & \\
\hline Restinga da Marambaia, RJ & 7.6 & 58 & Pereira et al. (2012) \\
\hline Ubatuba, SP & 7.7 & - & Assis et al. (2011) \\
\hline Average & 9.7 & 65 & \\
\hline \multicolumn{4}{|l|}{ Atlantic Rain Forest } \\
\hline Ilha do Cardoso, SP & 6.3 & 70 & Moraes et al. (1999) \\
\hline Guarujá, SP & 7.9 & 64 & Varjabedian \& Pagano (1988) \\
\hline Ilha Grande, RJ & 10.7 & - & Oliveira (2004) \\
\hline Rio de Janeiro, RJ & 7.5 & 64 & Oliveira et al. (2005) \\
\hline Ilha da Marambaia, RJ & 7.9 & 66 & Pereira et al. (2008) \\
\hline Recife, PE & 10.1 & 67 & Espig et al. (2009) \\
\hline Ubatuba, SP & 8.8 & - & Assis et al. (2011) \\
\hline Average & 8.5 & 66 & \\
\hline
\end{tabular}

the soil in Atlantic Rain Forests (Assis et al., 2011). Thus, leaching of cations from the soil is more intensive in restingas, which limits primary productivity and, consequently, litter deposits. In addition, non-flooding restinga forests also present lower litterfall than in flooding restinga forests. This is probably a result of hydric stress in the non-flooding restinga, which limits vegetation growth in this ecosystem.

The production of litter is a function of primary productivity. Therefore, it depends fundamentally on the structure of the tree community (Clark et al., 2001). When comparing the non-flooding restinga forests to each other, the higher annual total litter deposits in the dune forest in Marambaia is due to the taller tree community, which ranges from 8 to $15 \mathrm{~m}$. On the other hand, the tree community in Ilha do Cardoso is lower and ranges from 4 to $7 \mathrm{~m}$ (Moraes et al., 1999), whereas in Ilha do Mel the average height is $3 \mathrm{~m}$, with the tallest trees reaching a maximum of $5 \mathrm{~m}$ (Pires et al., 2006).

The contribution of leaves to total litterfall was higher, followed by twigs, whereas the others fractions together represented only $9 \%$ of the total litterfall, in both Year1 and Year2 (Table 1). This result corroborated the pattern commonly observed in the literature.
According to the Table 2, the contribution of leaves ranges from 58 to $75 \%$. The variation in terms of the relative contribution of leaves, and other litter fractions in the total annual litterfall, is due to differences between ecosystems in terms of the forest structure, which is a consequence of the successional stage or degree of disturbance, as well as the climatic conditions of the site, such as precipitation and atmospheric moisture (Barbosa \& Faria, 2006).

Total litterfall deposits and its fractions were continuous throughout Year1 and Year2 (Figure 2). In tropical rain forests without a severe drought period, the processes of senescence and emergence of new leaves occurs throughout the year (Morellato et al., 2000). However, in Year1 significant differences between the months occurred, within Year1, in terms of leaf $(p=0.000000)$, twig $(p=0.000984)$, flower $(p=0.000355)$, fruit $(\mathrm{p}=0.000000)$, and total litterfall $(\mathrm{p}=0.000000)$ deposits. On the other hand, no differences in refuse deposits ( $p=0.651100)$ was observed between the months, in Year1.

In Year1, leaf deposits were significantly higher $(\mathrm{p}<0.05)$ in September/1999 and January/2000 (0.70 and $0.74 \mathrm{t} \mathrm{ha}^{-1}$ month $^{-1}$, respectively). The same 

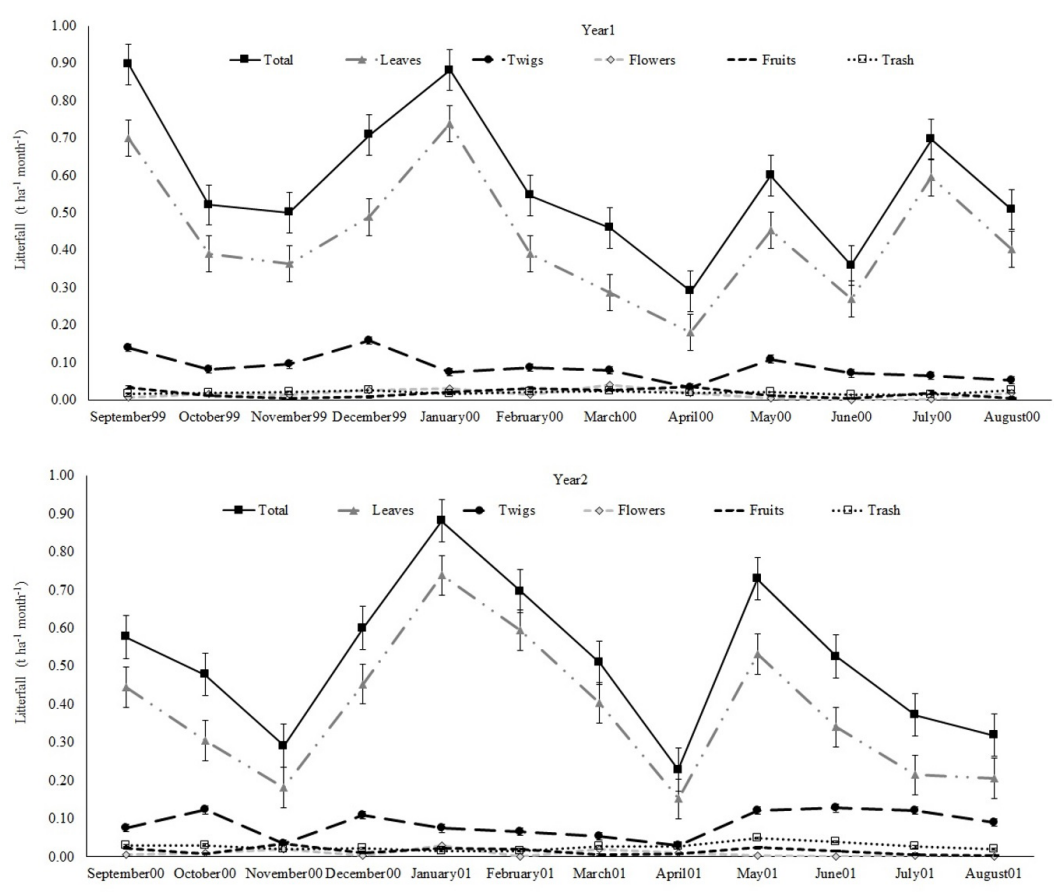

Figure 2. Annual distribution of litterfall (total and fractions, $\mathrm{t} \mathrm{ha}^{-2} \mathrm{month}^{-1}$ ) over Year1 and Year2, in a forest dune at Restinga da Marambaia, Rio de Janeiro State, Brazil.

pattern of higher deposits during the rainy season occurred for twigs (December/2000: $0.16 \mathrm{tha}^{-1} \mathrm{month}^{-1}$ ), flowers (March/2000: $0.04 \mathrm{t} \mathrm{ha}^{-1}$ month $^{-1}$ ), fruits (September/2000: $0.03 \mathrm{t} \mathrm{ha}^{-1}$ month $^{-1}$ ), and total litterfall (September/1999 and January/2000: 0.90 and $0.88 \mathrm{t} \mathrm{ha}^{-1}$ month $^{-1}$, respectively). In contrast, there were no significant differences between the months in terms of refuse deposits in Year1. In Year2, there were significant differences between the months, for leaf $(p=0.00)$, twig $(p=0.000403)$, flower $(p=0.001162)$, fruit $(\mathrm{p}=0.049027)$, refuse $(\mathrm{p}=0.000253)$, and total litterfall $(\mathrm{p}=0.00)$ deposits.

The highest leaf (January and February/2001), flower (January/2001), fruit (November/2001), and total litterfall (January/2001) deposits were observed in the rainy season, in Year2 (Figure 2). On the other hand, the highest twig (June/2001) and refuse (May/2001) deposits occurred in the middle of the dry season of the same year. These results indicated that litterfall was higher during the rainy season. This pattern was also observed in the non-flooding restinga forests in Ilha do Cardoso (Moraes et al., 1999), Ilha do Mel (Pires et al., 2006) and in seasonally flooding restinga forests in Marambaia (Paula et al., 2009). In non-flooding and flooding restinga forests in Ilha do Mel, the production of new leaves and senescent leaf deposits occurred continuously over two years of observation, but both conditions were more marked during the rainy season (Marques \& Oliveira, 2004).

Similarly, it was expected that litter deposits would have been greater in Year2, due to higher annual precipitation and monthly average temperature $\left(1,231.1 \mathrm{~mm}\right.$ and $25.3{ }^{\circ} \mathrm{C}$, respectively) values, in comparison with Year $1\left(1,062.2 \mathrm{~mm}\right.$ and $24.2^{\circ} \mathrm{C}$, respectively). However, we observed the opposite, because the total litterfall, influenced by both leaf and flower fractions, was higher in Yearl. The absence of a pattern in the leaf deposits was also verified in non-flooding and flooding restinga forests in Ilha do Mel, when comparing two consecutive years in each type of forest (Marques \& Oliveira, 2004). These authors indicated that other factors such as day length influenced litterfall.

The generalized linear model analysis in Year1 indicated a significant impact of both precipitation and temperature on leaf deposits $(\mathrm{p}=0.000148$, and 
$\mathrm{p}=0.016070$, respectively). Although precipitation significantly influenced total litterfall deposits $(p=0.003277)$, this pattern was not verified for temperature $(\mathrm{p}=0.249819)$. Temperature significantly influenced flower deposits ( $\mathrm{p}=0.004725)$, whereas precipitation did not influence deposits of this fraction $(\mathrm{p}=0.293811)$. On the other hand, neither precipitation nor temperature showed a significant impact on twig ( $\mathrm{p}=0.068439$ and $\mathrm{p}=0.105603$, respectively), fruit ( $p=0.868651$ and $p=0.117804$, respectively), or refuse ( 0.675173 and $\mathrm{p}=0.269565$, respectively) deposits.

According to the generalized linear model analysis for Year2, temperature significantly influenced leaf $(\mathrm{p}=0.000009)$, twig $(\mathrm{p}=0.002344)$, flower $(\mathrm{p}=0.002303)$, refuse $(\mathrm{p}=0.001086)$, and total litterfall $(\mathrm{p}=0.001836)$ deposits, whereas precipitation did not influence deposits of these fractions $(\mathrm{p}=0.472579, \mathrm{p}=0.369232$, $\mathrm{p}=0.909823$, and $\mathrm{p}=0.093873$, respectively) or total litterfall ( $\mathrm{p}=0.531493)$. Neither precipitation nor temperature showed a significant impact on fruit deposits ( $\mathrm{p}=0.153749$ and $\mathrm{p}=0.882278$, respectively).

Therefore, in the present study, temperature seemed to have a more decisive impact on litterfall, in comparison to precipitation. This result may occur in areas without a severe drought period, where variations in day length and temperature throughout the year have a greater impact than precipitation on phenology (Morellato et al., 2000).

In the forest dune in Restinga da Marambaia, the litter lying on the forest floor tended to be less in December/1999 and greater in March/2000, in Year1. However, in Year2, lower values occurred in June/2001, whereas higher values were observed in December/2000 (Table 3). The average annual litter lying on the forest floor estimated was $9.8 \mathrm{t} \mathrm{ha}^{-1} \mathrm{yr}^{-1}$ and $7.4 \mathrm{t} \mathrm{ha}^{-1} \mathrm{yr}^{-1}$ in Year1 and Year2, respectively, The decomposition rate $(\mathrm{K})$ was 0.74 and the time needed to complete renewal of litter accumulated on the forest floor (tr) was 1.35 years (489 days), in Year1.
However, in Year2, the value of $\mathrm{K}$ was 0.95 and tr was 1.05 years (382 days).

This result of faster litter decomposition was probably due to both higher annual precipitation $(1,233.1 \mathrm{~mm})$ and monthly average temperature $\left(25.3^{\circ} \mathrm{C}\right)$ in Year2, in comparison with Year1 $\left(1,062.2 \mathrm{~mm}\right.$ and $24.2^{\circ} \mathrm{C}$, respectively). In tropical forests, warmer, more humid climatic conditions favor the activity of the decomposing biota, which increases the rate of litter decomposition (Powers et al., 2009; Campo \& Merino, 2016).

Considering the average values calculated between Year 1 and Year2, $\mathrm{K}$ and tr were 0.85 and 1.20 years (439 days), respectively. In tropical forests, the $K$ values are generally higher than 1.00 , indicating that the turnover time of litter in these ecosystems occurs in less than one year (Golley et al., 1978), featuring a rapid process of decomposition and intense nutrient cycling (Olson, 1963). The results indicated that the litter turnover in the present study was slower than in a non-flooding restinga forest $(\mathrm{K}=0.92$; $\operatorname{tr}=398$ days $)$ in Ilha do Mel (Pires et al., 2006) and in a fragment of Atlantic Rain Forest $(\mathrm{K}=1.02 ; \mathrm{tr}=357$ days $)$ in Rio de Janeiro (Oliveira et al., 2005).

The differences between tropical forests in terms of the decomposition rate are mainly due to the activity of microbial decomposers, whose populations are regulated by the soil predator invertebrates and by soil saprophagous invertebrates, that breakdown the litter (Swift et al., 1979). In addition, climatic conditions (particularly precipitation and temperature), edaphic conditions (aeration, temperature, moisture and $\mathrm{pH}$ ), and the litter characteristics influence the activity of the decomposing microbiota (Swift \& Anderson, 1989). The litter characteristics are closely related to the palatability of the organic material available to decomposers (Maharning et al., 2009), which varies according to plant species (Villela \& Proctor, 2002). Litter with higher palatability consists of easily degradable compounds (Milcu \& Manning, 2011), with low phenolic

Table 3. Litter lying on the ground $\left(\mathrm{t} \mathrm{ha}^{-1} \mathrm{yr}^{-1}\right)$ at forest dune at Restinga da Marambaia, Rio de Janeiro State, Brazil.

\begin{tabular}{cccccc} 
Year1 & Sep/1999 & Dec/1999 & Mar/2000 & June/2000 & Average \\
& 10.1 & 9.2 & 10.2 & 9.6 & 9.8 \\
Year2 & Sep/2000 & Dec/2000 & Mar/2001 & June/2001 & Average \\
\hline & 7.4 & 9.0 & 7.9 & 5.2 & 7.4 \\
\hline
\end{tabular}


substance content and high N (Maharning et al., 2009) and other nutrient contents (Pinto \& Marques, 2003; Barbosa \& Faria, 2006).

In restingas, the slower decomposition (Bonadiman, 2007) is influenced by the low nutrient quality of the litter (Castanho \& Oliveira, 2008; Pereira et al., 2012). Therefore, the return of nutrients to the soil is gradual (Bonadiman, 2007) and the nutrient demand of plants is met through litter mineralization (Correia \& Andrade, 2008). Additionally, such elements present high efficiency of use because they are internally translocated from mature to new leaves before their senescence (Moraes \& Domingos, 1997). Further, slower decomposition would increase the organic layer and mineral soil carbon storage in these forest ecosystems, which could function as relevant soil carbon sinks (Campo \& Merino, 2016).

Thus, slower decomposition combined with low litter production indicates that there is a synchronism between these processes, which is advantageous for the plant community in these ecosystems (Pires et al., 2006) because it minimizes the leaching of nutrients from the sandy soil with low fertility in such ecosystems (Moraes et al., 1999; Assis et al., 2011; Camara et al., 2016). This dynamic is responsible for the high plant diversity in restingas, despite the low fertility of the sandy soils (Castanho \& Oliveira, 2008) and the other extreme abiotic conditions, which include heat, flooding, drought, wind, and salinity (Scarano et al., 2001).

\section{CONCLUSIONS}

Litterfall was higher in the Year1, in comparison to Year2.

Litter deposits were higher in the rainy season in both years, and were mainly influenced by temperature, and less influenced by precipitation.

The rate of decomposition and the turnover time of litter was faster in the Year2 than in Year1.

The litter dynamic (deposits and decomposition) was slower in the forest dune in comparison to other forest ecosystems in the Atlantic Rainforest biome.

\section{SUBMISSION STATUS}

Received: 30 mar., 2017

Accepted: 1 aug., 2017

\section{CORRESPONDENCE TO}

\section{Marcos Gervasio Pereira}

Departamento de Solos, Universidade Federal Rural do Rio de Janeiro - UFRRJ, BR 465, Km 7 , CEP 23890-000, Seropédica, RJ, Brasil

e-mail: gervasio@ufrrj.br

\section{REFERENCES}

Alvares CA, Stape JL, Sentelhas PC, Gonçalves JLM, Sparovek G. Koppen's climate classification map for Brazil. Meteorologische Zeitschrift 2013; 22(6): 711-728. http:// dx.doi.org/10.1127/0941-2948/2013/0507.

Arato HD, Martins SV, Ferrari SHS. Produção e decomposição de serapilheira em um sistema agroflorestal implantado para recuperação de área degradada em Viçosa-MG. Revista Árvore 2003; 27(5): 715-721. http://dx.doi.org/10.1590/ S0100-67622003000500014.

Assis MA, Prata EMB, Pedroni F, Sanchez M, Eisenlohr PV, Martins FR et al. Florestas de restinga e de terras baixas na planície costeira do sudeste do Brasil: vegetação e heterogeneidade ambiental. Biota Neotropica 2011; 11(2): 103-121. http://dx.doi.org/10.1590/S167606032011000200012 .

Barbosa JHC, Faria SM. Aporte de serrapilheira ao solo em estágios sucessionais florestais na Reserva Biológica de Poço das Antas, Rio de Janeiro, Brasil. Rodriguésia [online]. 2006; 57(3): 461-476. [cited 2017 Mar 30]. Available from: http://www.jstor.org/stable/23498740

Bonadiman GSL. Decomposição e liberação de nutrientes de folhas de Clusia hilariana Schlcth (Clusiaceae) em moitas da formação Arbustiva Aberta de Clusia no Parque Nacional da Restinga de Jurubatiba, RJ. [dissertação]. Campos dos Goytacazes: Universidade Estadual do Norte Fluminense Darcy Ribeiro; 2007.

Camara R, Pereira MG, Silva CF, Paula RR, Silva EMR. Fungos micorrízicos arbusculares em dois fragmentos florestais de restinga periodicamente inundável em Marambaia, RJ. Floresta e Ambiente 2016; 23(1): 33-42. http://dx.doi.org/10.1590/2179-8087.072214.

Campo J, Merino A. Variations in soil carbon sequestration and their determinants along a precipitation gradient in seasonally dry tropical forest ecosystems. Global Change Biology 2016; 22(5): 1942-1956. http://dx.doi.org/10.1111/ gcb.13244. PMid:26913708.

Castanho CT, Oliveira AA. Relative effect of litter quality, forest type and their interaction on leaf decomposition in south-east Brazilian forests. Journal of Tropical Ecology 2008; 24(02): 149-156. http://dx.doi.org/10.1017/ S0266467407004749.

Chave J, Navarrete D, Almeida S, Álvarez E, Aragão LEOC, Bonal D et al. Regional and seasonal patterns of 
litterfall in tropical South America. Biogeosciences 2010; 7(1): 43-55. http://dx.doi.org/10.5194/bg-7-43-2010.

Clark DA, Brown S, Kicklighter DW, Chambers JQ, Thomlinson JR, Ni J. Measuring net primary production in forests: concepts and field methods. Ecological Applications 2001; 11(2): 356-370. http://dx.doi.org/10.1890/10510761(2001)011[0356:MNPPIF]2.0.CO;2.

Cogliatti-Carvalho L, Freitas AFN, Rocha CFD, Van Sluys M. Variação na estrutura e na composição de Bromeliaceae em cinco zonas de restinga no Parque Nacional da Restinga de Jurubatiba, Macaé, RJ. Revista Brasileira de Botanica. Brazilian Journal of Botany 2001; 24(1): 1-9. http://dx.doi. org/10.1590/S0100-84042001000100001.

Correia GGS, Martins SV, Miranda Neto A, Silva KA. Estoque de serapilheira em floresta em restauração e em Floresta Atlântica de tabuleiro no sudeste brasileiro. Revista Árvore 2016; 40(1): 13-20. http://dx.doi.org/10.1590/010067622016000100002 .

Correia MEF, Andrade AG. Formação de serapilheira e ciclagem de nutrientes. In: Santos GA, Camargo FAO, editores. Fundamentos da matéria orgânica do solo: ecossistemas tropicais e subtropicais. Porto Alegre: Gênesis; 2008. p. 137-170.

Espig AS, Freire FJ, Marangon LC, Ferreira RLC, Freire MBGS, Espig DB. Sazonalidade, composição e aporte de nutrientes da serapilheira em fragmento de mata atlântica. Revista Árvore 2009; 33(5): 949-956. http:// dx.doi.org/10.1590/S0100-67622009000500017.

Fraga ME, Pereira MG, Souza FA. Micobiota do solo de uma área de duna na Restinga da Marambaia, Rio de Janeiro, RJ. Floresta e Ambiente 2010; 17(1): 30-36. http:// dx.doi.org/10.4322/floram.2011.007.

Golley FB, McGinnis JT, Clements RG, Child GI, Duever MJ. Ciclagem de minerais em um ecossistema de floresta tropical úmida. São Paulo, EPU/EDUSP; 1978. 256 p.

Hopkins B. Vegetation of the Olokemeji Forest Reserve, Nigeria: IV. The litter and soil with special reference to their seasonal changes. Journal of Ecology 1966; 54(3): 687-703. http://dx.doi.org/10.2307/2257811.

Lopes MIS, Domingos M, Struffaldi-de-Vuono Y. Ciclagem de nutrientes minerais. In: Sylvestre LS, Rosa MMT. Manual metodológico para estudos botânicos na Mata Atlântica. Seropédica: EDUR-UFRRJ; 2002. p. 72-102.

Maharning AR, Mills AAS, Adl SM. Soil community changes during secondary succession to naturalized grasslands. Applied Soil Ecology 2009; 41(2): 137-147. http://dx.doi.org/10.1016/j.apsoil.2008.11.003.

Marques MCM, Oliveira PEAM. Fenologia de espécies do dossel e do sub-bosque de duas Florestas de Restinga na Ilha do Mel, sul do Brasil. Brazilian Journal of Botany 2004; 27(4): 713-723. http://dx.doi.org/10.1590/S010084042004000400011 .
Menezes LFT, Araújo DSD, Nettesheim FC. Estrutura comunitária e amplitude ecológica do componente lenhoso de uma fl oresta de restinga mal drenada no sudeste do Brasil. Acta Botanica Brasílica 2010; 24(3): 825-839. http:// dx.doi.org/10.1590/S0102-33062010000300025.

Menezes LT, Peixoto AL, Araújo DSD. História natural da Marambaia. Seropédica: EDUR; 2005. 288 p.

Milcu A, Manning P. All size classes of soil fauna and litter quality control the acceleration of litter decay in its home environment. Oikos 2011; 120(9): 1366-1370. http:// dx.doi.org/10.1111/j.1600-0706.2010.19418.x.

Moraes RM, Delitti WBC, Struffaldi-De Vuono Y. Litterfall and litter nutrient content in two Brazilian Tropical Forests. Revista Brasileira de Botânica 1999; 22(1): 9-16. http://dx.doi.org/10.1590/S0100-84041999000100002.

Moraes RM, Domingos M. Elementos minerais em folhas de espécies arbóreas de Mata Atlântica e Mata de Restinga, na Ilha do Cardoso, SP. Brazilian Journal of Botany 1997; 20(2): 133-138. http://dx.doi.org/10.1590/ S0100-84041997000200004.

Morellato LPC, Talora DC, Takahasi A, Bencke CC, Romera EC, Zipparro VB. Phenology of Atlantic Rain Forest trees: a comparative study. Biotropica 2000; 32(4b): 811-823. http://dx.doi.org/10.1111/j.1744-7429.2000.tb00620.x.

Oliveira RR, Silveira CLP, Magalhães AC, Firme RP. Ciclagem de metais pesados na serapilheira de uma floresta urbana no Rio de Janeiro. Floresta e Ambiente 2005; 12(1): 50-56.

Oliveira RR. Importância das bromélias epífitas na ciclagem de nutrientes da Floresta Atlântica. Acta Botanica Brasílica 2004; 18(4): 793-799. http://dx.doi.org/10.1590/ S0102-33062004000400009.

Olson JS. Energy storage and the balance of producers and decomposers in ecological systems. Ecology 1963; 44(2): 322-331. http://dx.doi.org/10.2307/1932179.

Patricia L, Morellato C. Nutrient cycling in two SouthEast Brazilian Forests. I Litterfall and litter standing crop. Journal of Tropical Ecology 1992; 8(2): 205-215. http:// dx.doi.org/10.1017/S0266467400006362.

Paula RR, Pereira MG, Menezes LFT. Aporte de nutrientes e decomposição da serapilheira em três fragmentos florestais periodicamente inundados na Ilha da Marambaia, RJ. Ciência Florestal 2009; 19(2): 139-148. http://dx.doi. org/10.5902/19805098405.

Pereira MG, Menezes LFT, Schultz N. Aporte e decomposição da serapilheira na Floresta Atlântica, Ilha da Marambaia, Mangaratiba, RJ. Ciência Florestal 2008; 18(4): 443-454. http://dx.doi.org/10.5902/19805098428.

Pereira MG, Menezes LFT, Silveira Filho TB, Silva NA. Propriedades químicas de solos sob Neoregelia cruenta (R. Grah) L.B. Smith na restinga da Marambaia, RJ. Floresta e Ambiente 2005; 12(1): 70-73. 
Pereira MG, Silva AN, Paula RR, Menezes LFT. Aporte e decomposição de serapilheira em floresta periodicamente inundável na Restinga da Marambaia, RJ. Ciência Florestal 2012; 22(1): 59-67. http://dx.doi.org/10.5902/198050985079.

Pinto CB, Marques R. Aporte de nutrientes por frações da serapilheira em sucessão ecológica de um ecossistema da Floresta Atlântica. Revista Floresta 2003; 33(3): 257-264.

Pires LA, Britez RM, Martel G, Pagano SN. Produção, acúmulo e decomposição da serapilheira em uma restinga da Ilha do Mel, Paranaguá, PR, Brasil. Acta Botanica Brasílica 2006; 20(1): 173-184. http://dx.doi.org/10.1590/ S0102-33062006000100016.

Powers JS, Montgomery RA, Adair EC, Brearley FQ, DeWalt SJ, Castanho CT et al. Decomposition in tropical forests: a pan-tropical study of the effects of litter type, litter placement and mesofaunal exclusion across a precipitation gradient. Journal of Ecology 2009; 97(4): 801-811. http:// dx.doi.org/10.1111/j.1365-2745.2009.01515.x.

Rocha CFD, Bergallo HG, Van Sluys M, Alves MAS, Jamel $\mathrm{CE}$. The remnants of restinga habitats in the brazilian Atlantic Forest of Rio de Janeiro state, Brazil: Habitat loss and risk of disappearance. Brazilian Journal of Biology = Revista Brasileira de Biologia 2007; 67(2): 263-273. http://dx.doi.org/10.1590/S1519-69842007000200011. PMid:17876436.

Roncarati H, Menezes LFT. Marambaia, Rio de Janeiro: origem e evolução. In: Menezes LFT, Peixoto AL, Araujo DSD. História Natural da Marambaia. Seropédica: Editora da Universidade Federal Rural do Rio de Janeiro; 2005. p. 15-38.

Scarano FR, Duarte HM, Ribeiro KT, Rodrigues PJFP, Barcellos BEM, Franco AC et al. Four sites with contrasting environmental stress in southeastern Brazil: relations of species, life form diversity, and geographic distribution to ecophysiological parameters. Botanical Journal of the Linnean Society 2001; 136(4): 345-364. http://dx.doi. org/10.1111/j.1095-8339.2001.tb00579.x.

Souza RC, Pereira MG, Menezes LFT, Silveira Filho TB, Silva NA. Role of terrestrial bromeliads in nutrient cycling, Restinga da Marambaia, Brazil. Floresta e Ambiente 2016; 23(2): 161-169. http://dx.doi.org/10.1590/2179-8087.106414.

Swift MJ, Anderson JM. Decomposition. In: Lieth H, Werger MJ, editores. Tropical rain forest ecosystems: biogeographical and ecological studies: ecosystems of the world. New York: Elsevier Science; 1989. p. 547-569. http://dx.doi.org/10.1016/B978-0-444-42755-7.50037-7.

Swift MJ, Heal OW, Anderson JM. Decomposition in terrestrial ecosystems. Oxford: Blackwell Scientific Publications; 1979. 372 p.

Varjabedian R, Pagano SN. Produção e decomposição de folhedo em um trecho de Mata Atlântica de encosta no município do Guarujá, SP. Acta Botanica Brasílica 1988; 1(2): 243-256. http://dx.doi.org/10.1590/S010233061987000300023 .

Villela DM, Proctor J. Leaf litter decomposition and monodominance in the Peltogyne forest of Maracá Island, Brazil. Biotropica 2002; 34(3): 334-347.

Vital ART, Guerrini IA, Franken WK, Fonseca RCB. Produção de serrapilheira e ciclagem de nutrientes de uma floresta estacional semidecidual em zona ripária. Revista Árvore 2004; 28(6): 793-800. http://dx.doi.org/10.1590/ S0100-67622004000600004.

Vitousek PM, Sanford RL Jr. Nutrient cycling in moist tropical forest. Annual Review of Ecology and Systematics 1986; 17(1): 137-167. http://dx.doi.org/10.1146/annurev. es.17.110186.001033. 